\title{
Rediscovery of Armiger crista (Linnaeus, I 857) (Gastropoda Planorbidae) in Algeria
}

\author{
Ramdini Ramdane ${ }^{\text {I, }}$, Dirk Van Damme², Sadouk Ghania' \& Medjdoub-Bensaad Ferroudja'
}

${ }^{1}$ Laboratoire de Production, sauvegarde des espèces menacées et des récoltes, Influence des variations climatiques, Département de Biologie, Faculté des Sciences Biologiques et des Sciences Agronomiques, Université Mouloud Mammeri de Tizi-Ouzou, 15000

${ }^{2}$ Research Unit Paleontology, Geological Institute, Ghent University, Belgium; email: dirk.vandamme@ugent.be ${ }^{*}$ Corresponding author, email: ramdane.ramdini@ummto.dz

\begin{abstract}
Armiger crista (Linnaeus, 1758), a holartic freshwater gastropod, has been rediscovered in Algeria. It was found in a small lake whose malacofauna was almost exclusively paleartic/holartic. This aquatic environment is probably unique in the Maghreb, where cold-climate faunal elements are rapidly disappearing due to global warming. Monitoring of the site and study of other groups is highly recommended.
\end{abstract}

KEY WORDS Armiger crista; endangered paleartic gastropods; global climate change; southern limit.

Received 08.07.2020; accepted 19.08.2020; published online 06.11.2020

\section{INTRODUCTION}

Armiger crista (Linnaeus, 1758), type locality: marshes in Germany, is a holartic freshwater/ $\alpha$ oligohaline pulmonate gastropod, belonging to the family Planorbidae. The Maghreb and Ethiopia constitute in Africa the southern limit of its range (Van Damme, 1984; Brown, 1994). In the last decades it has only been recorded from a few sites, namely at Ifrane, Lake Hachlaf and the Ben Smim springs in the Middle Atlas in Morocco (Ghamizi, 1998) and from a well at Jandouba, north-west Tunisia (Khalloufi \& Boumaiza, 2007).

In Algeria, it was considered as possibly extinct (Van Damme \& Ghamizi, 2010, Van Damme et al., 2010), not being recorded anymore since the $19^{\text {th }}$ Century, when Bourguignat (1864) listed it as Planorbis crista and P. imbricatus $(=$ P. crista), from the Mediterranean region between Mostaganem and Constantine (see also Lallemant, 1881).
Subfossils shells have been found in the southern part of the country at Hassi-Dehin and the Ahaggar Mountains (Sparks \& Grove, 1961; see also: Thomas 1884: 50-51, tableau synoptique and Pallary, 1901: 160).

In July, 2020, during an inventory survey of the malacological fauna of Algeria, specimens of Armiger crista were found in a small lake near TiziOuzou.

\section{MATERIAL AND METHODS}

Sampling was carried out in the region of TiziOuzou, about $100 \mathrm{~km}$ east of Algiers (Algeria). The site is a natural lake, shallow, with a length of 80 meters and a width of 30 meters, it is rich in vegetation and animals occupying this habitat, located at an altitude of 460 meters with coordinates $36^{\circ} 48^{\prime} 14^{\prime \prime} \mathrm{N}, 4^{\circ} 00^{\prime} 35^{\prime \prime} \mathrm{E}$ (Fig. 1). 
The samples (Fig. 2), a dozen specimens of Armiger crista, were taken with a hand net $(0.5$ $\mathrm{mm}$-mesh size). The shell shows regular transverse ridges extending beyond the main curve of the shell. It is translucent, yellow-brownish in colour and has had a maximum diameter $1.83-2.19 \mathrm{~mm}$.

Other additional species were found in this place, such as Hippeutis complanatus (Linnaeus, 1758), Bulinus truncatus (Michaud, 1829), Ferrissia californica (Rowell, 1863), Musculium lacustre (O.F. Müller, 1774), and Planorbis planorbis (Linnaeus, 1758).

\section{DISCUSSION AND CONCLUSIONS}

Since the late $19^{\text {th }}$ Century little field-work has been carried out on the freshwater malacofauna of Algeria. Nonetheless, it is evident that, due to the ever intensifying and unsustainable human use of surface waters, many of these have disappeared or become devoid of aquatic life since that time. In addition, increasing ambient temperatures and extended periods of drought, due to climate change, have in the last decades aggravated this ecological decline (Oualkacha et al., 2017). In all Maghrebian countries, the freshwater gastropod fauna in general has severely suffered, but in particular the palearticholartic species, whose range's southern limit was situated in northern Africa and the Levant. These are presently vanishing all over their historical southern range (Seddon et al., 2014).

The discovery in Algeria of a standing surface water, where $H$. complanatus $\mathrm{L}$. was found (Glöer \& Ramdini, 2019), harboring not only Armiger crista, considered as endangered, but harboring a mollusc community consisting almost exclusively of holartic molluscs, Bulinus truncatus excepted, is of substantial scientific importance. It indicates that such aquatic relict environments still exist in the Maghreb, though having become extremely rare. It is therefore highly recommended that the small lake in question should be protected, considering its ecological uniqueness and that a monitoring program should be set up to track changes in abiotic and biotic (e.g., molluscs) parameters over time in function of global warming trends in the Maghreb.

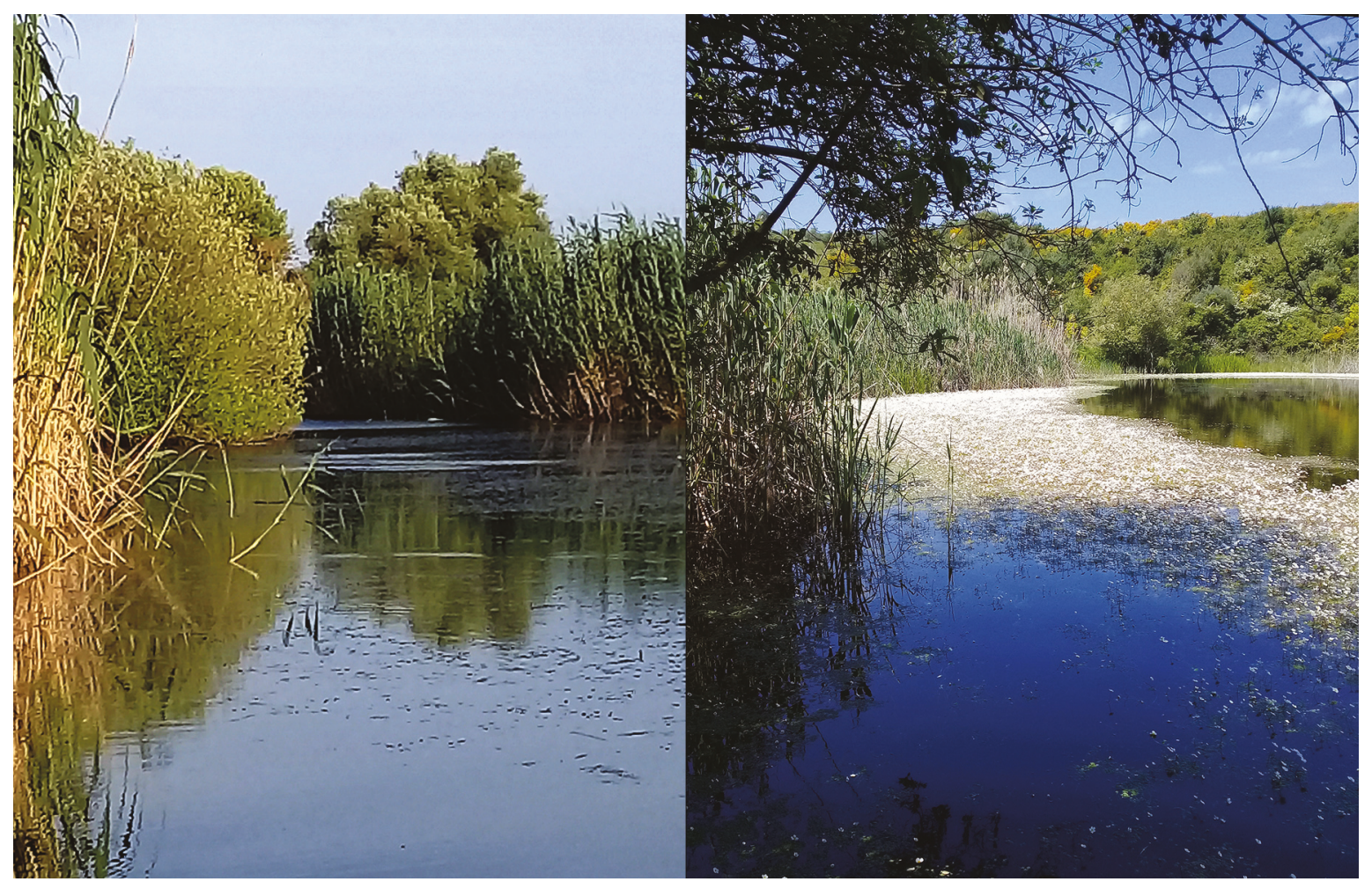

Figure 1. Small lake near Tizi-Ouzou (Algeria). 


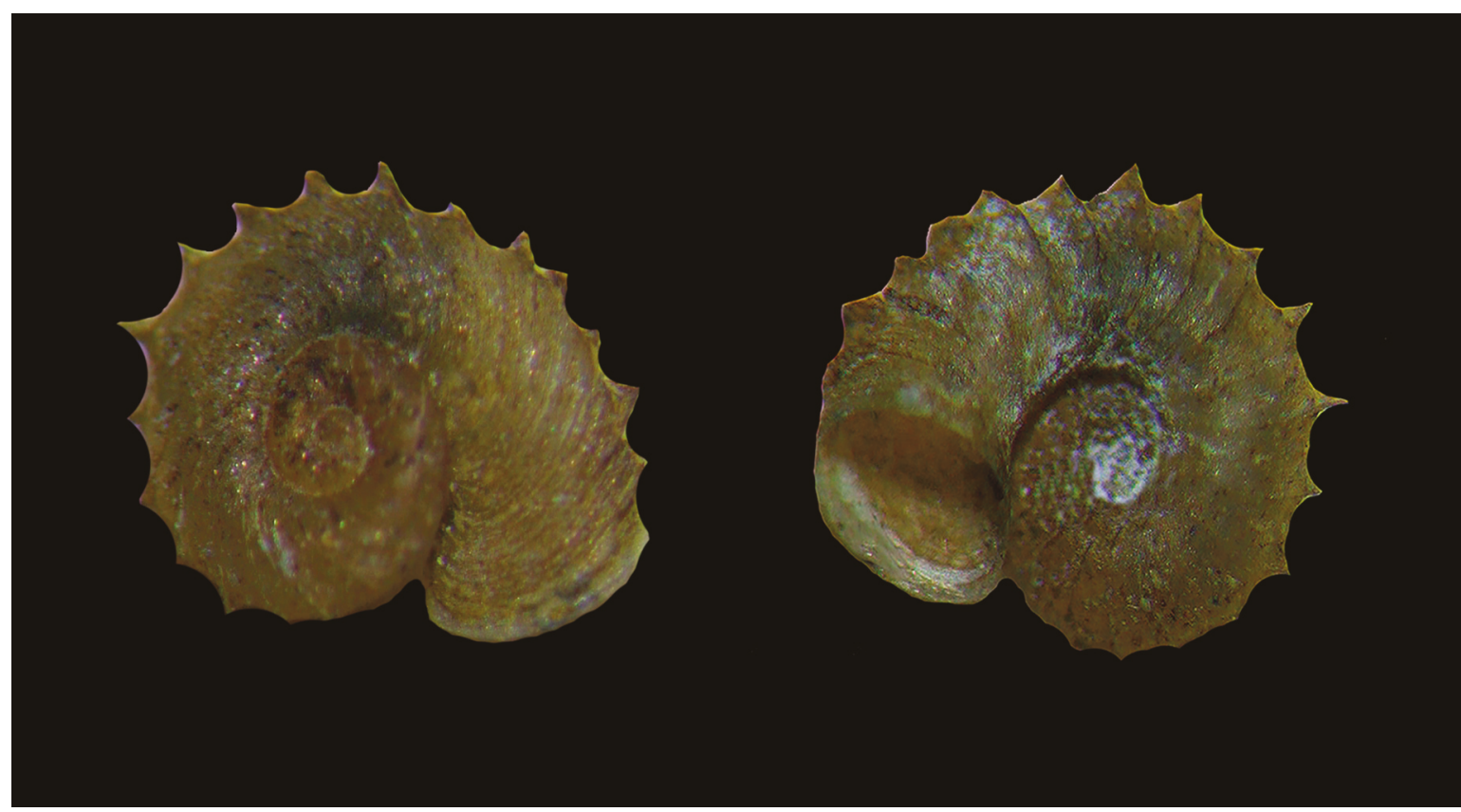

Figure 2. Armiger crista from Tizi-Ouzou (Algeria), maximum diameter $1.94 \mathrm{~mm}$.

\section{REFERENCES}

Bourguignat J.R., 1864. Malacologie de l'Algérie ou histoire naturelle des animaux mollusques terrestres et fluviatiles recueillis jusqu'à ce jour dans nos possessions du nord de l'Afrique, tome 2, $380 \mathrm{pp}$.

Brown D.S., 1994. Freshwater snails of Africa and their medical importance. 2nd ed., 609 pp.

Ghamizi M., 1998. Les Mollusques des eaux continentales du Maroc: Systématique et Bioécologie. Thèse de doctorat. Faculté des Sciences Semlalia, Université Cadi Ayyad, Marrakech.

Glöer P. \& Ramdini R., 2019. Hippeutis complanatus Linnaeus, 1758 in Algeria, Re-Found after More than 150 Years. Ecologica Montenegrina, 22: 226-27. https://doi.org/10.37828/em.2019.22.18.

Khalloufi N. \& Boumaiza M., 2007. Première citation et description de quatre pulmonés dulcicoles de Tunisie (Mollusca, Orthogastropoda). Bulletin de la société zoologique de la France, 132: 191-204.

Lallemant Ch.,1881. Catalogue des mollusques terrestres et fluviatiles des environos d'Alger. Feuille des Jeunes Naturalistes, 11 (126): 83-88.
Oualkacha L., Stour L., Agoumi A. \& Kettab A., 2017. Climate Change Impacts in the Maghreb Region: Status and Prospects of the Water Resources. In: Mohamed Ouessar, Donald Gabriels, Atsushi Tsunekawa, and Steven Evett (Eds.), Water and Land Security in Drylands, pp. 17-25. Cham: Springer International Publishing. https://doi.org/10.1007/9783-319-54021-4_2.

Pallary P., 1901. Sur les mollusques fossiles terrestres, fluviatiles et saumâtres de l'Algérie. Mémoires de la Société Géologique de France, Paléontologie, 9: 1213, Pl. III-VI [=3-6].

Seddon M., Kebapp U, Lopes-Lima M., Van Damme D. \& Smith K., 2014. Chapter 4. Freshwater Molluscs. In: Smith K., Barios V., Darwall W. \& Numa C. (Eds.), The status and distribution of freshwater biodiversity in the Eastern Mediterranean. IUCN, Cambridge: pp. 43-56.

Sparks B. W. \& Grove A. T., 1961. Some quaternary fossil non-marine mollusca from the central Sahara. Journal of the Linnean Society of London, Zoology 44 (298): 355-364. https://doi.org/10.1111/j.1096-3642.1961. tb01619.x.

Thomas P., 1884. Recherches stratigraphiques et paléontologiques sur quelques formations d'eau douce de 
l'Algerie II. Mémoires de la société géologique de France, 3: 1-51.

Van Damme D., 1984. The freshwater Mollusca of Northern Africa. Distribution, Biogeography and Palaeoecology. Dordrecht, Netherlands, 164 pp.

Van Damme D. \& Ghamizi M., 2010. Gyraulus crista. The IUCN Red List of Threatened
Species 2010: e.T156006A4884981.

Van Damme D., Ghamizi M., Soliman G., McIvor A. \& Seddon M.B., 2010. The status and distribution of freshwater molluscs. In: García N., Cuttelod A. \& Abdul Malak D. (Eds.), The Status and Distribution of Freshwater Biodiversity in Northern Africa. IUCN: $30-50$. 